\title{
Organometallic complexes as anion hosts
}

\author{
Julio Pérez* and Lucía Riera \\ Received (in Cambridge, UK) 2nd August 2007, Accepted 13th September 2007 \\ First published as an Advance Article on the web 27th September 2007 \\ DOI: 10.1039/b711910k
}

New anion hosts have been accessed using cationic organometallic fragments with sufficient kinetic stability as geometry-organizing cores, simple ditopic ligands featuring hydrogen bond donor groups, and the inert, low interacting, lipophilic $\mathrm{BAr}^{\prime}{ }_{4}$ anion.

\section{Introduction}

Metal fragments are increasingly being used in the construction of hosts for anions ${ }^{1}$ and neutral molecules. ${ }^{2}$ Metals can act as Lewis-acidic binding sites or as sensing units, carry positive charge and increase the strength of non-covalent interactions such as hydrogen bonds. Metals can also play structural roles, such as restricting the conformations available to the host or acting as the core onto which the binding groups are assembled in the appropriate geometry. Our own work, of which this Article gives an account, focused on using simple mononuclear organometallic complexes as anion hosts. Due to our selection of simple ligand architectures, the geometry of the host is mainly an expression of the metal preferences. When using organometallic compounds as hosts, stability is always a prime concern. We have chosen metal fragments that are stable toward air and moisture, as well as against ligand substitution by the anion guest. Interestingly, Meggers et al. have recently employed kinetically inert metal complexes as elements of molecular scaffolding within the field of bioorganometallic chemistry. ${ }^{3}$

Departamento de Química Orgánica e Inorgánica I.U.Q.O.E.M., Facultad de Química, Universidad de Oviedo-C.S.I.C., 33006, Oviedo, Spain.E-mail:japm@uniovi.es; lrm@fq.uniovi.es; Fax:34 985103446; Tel: 34985103465

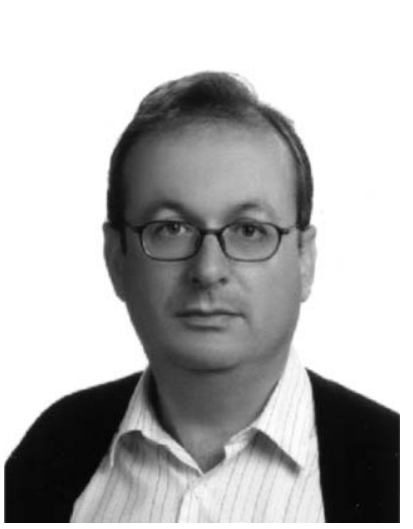

Julio Pérez

Julio Pérez (1964) was raised in Cangas del Narcea (Asturias). He received a PhD in Chemistry in 1993 at the Universidad de Oviedo working on bimetallic complexes with $\mathrm{R}_{3} \mathrm{P}-\mathrm{CS} \mathrm{S}_{2}$ adducts as bridging ligands under the guidance of Victor Riera and Daniel Miguel. After spending the years 1994-95 as a Fulbright visiting scholar at the University of North Carolina working with Maurice Brookhart and Joseph L. Templeton on organometallic chemistry and catalysis, he returned to Oviedo in 1996 on a research reintegration contract, was appointed Profesor Asociado later that year, and promoted to Profesor Titular in 2001. His interests include Organometallic Chemistry, Supramolecular Chemistry and Catalysis.
Competition between the counter-anion and the target guest is one of the limitations of cationic anion hosts. Our approach to this issue has been to employ the $\mathrm{BAr}^{\prime}{ }_{4}{ }^{-}\left(\mathrm{Ar}^{\prime}=3,5-\right.$ bis(trifluoromethyl)phenyl) tetraarylborate, widely used in organometallic chemistry, ${ }^{4}$ but not in host-guest chemistry, as counter-anion.

The ancillary ligands (i.e., those that complete the metal first coordination sphere but are not directly involved in anion binding) were found to dramatically influence the stability of the complex and its solubility, crucial features in the behavior of the complex toward anions. In some cases (see below) the nature of the ancillary ligands even dictates the geometry of the complex.

Recent works by the groups of Gale and Loeb, ${ }^{5}$ and Steed, ${ }^{6}$ have elegantly shown that simple coordination compounds containing a combination of positive charge and monodentate ligands featuring hydrogen bond donor groups can be used as anion hosts. The geometrical preferences of the metal center place the ditopic ligands in positions such that their hydrogen bond donor groups can converge toward an external guest. In contrast with purely organic hosts, for which attaining the right geometry can be synthetically challenging, those metalbased hosts are synthesized by simple addition or substitution reactions employing an easily available metal precursor and simple organic molecules. Monodentate pyrazoles and

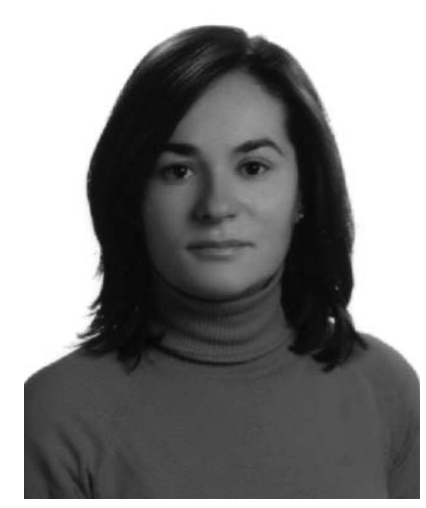

Lucía Riera

Lucía Riera (Zaragoza, 1974) received her PhD in Chemistry in 2002 at the Universidad de Oviedo (Victor Riera and Julio Perez) with a thesis on molybdenum allyl carbonyl compounds. In October 2002 she was awarded a Marie Curie postdoctoral fellowship to work with Dominic $S$. Wright at the University of Cambridge on the synthesis of new PN macrocycles. In January 2005 she returned to Oviedo as a Ramon y Cajal fellow and the holder of a Marie Curie European Reintegration Grant. Her main research interests are Organometallic Chemistry and Supramolecular Chemistry. 
bidentate biimidazole are examples of such ditopic molecules able to act as both ligands and hydrogen bond donors. The coordination chemistry of pyrazoles ${ }^{7}$ and biimidazole ${ }^{8}$ has been extensively studied, including their recent use as building blocks in the synthesis of hydrogen-bonded networks. However, the solution behavior of their complexes as anion hosts remained unexplored.

\section{Anionic tris(pyrazolyl)borate ligands and cationic tris(pyrazole) receptors}

Invented by Trofimenko in the 1960s, tris(pyrazolyl)borate (Tp) anions soon became some of the most popular ligands for a variety of purposes, including catalysis, bioinorganic and organometallic chemistry. ${ }^{9}$ In most instances, the three pyrazolate arms of $\mathrm{Tp}$ ligands strongly bind in a tridentate manner a metal center. Despite the fact that the $\mathrm{B}-\mathrm{N}$ bond of Tp ligands is sensitive to protolytic cleavage, ${ }^{10}$ a few examples of mono- or diprotonated Tp ligands or their complexes have been described. ${ }^{11}$ No triprotonated Tp ligand is known. Nevertheless, in 1991, Looney, Parkin and Rheingold reported the synthesis and structural characterization of the host-guest complex $\left[\mathrm{HB}\left(\mathrm{H}^{t} \mathrm{Bupz}\right)_{3} \cdots \mathrm{Cl}\right]^{+}\left(\mathrm{H}^{t} \mathrm{Bupz}=3(5)\right.$-tert-butylpyrazole), isolated as its tetrachloroaluminate salt, in which the chloride guest is hydrogen-bonded by the three $\mathrm{N}-\mathrm{H}$ tert-butylpyrazole groups of what it can be considered a triprotonated Tp ligand (Fig. 1, A). ${ }^{12}$ In 1994, Reger et al. isolated the compound $\left[\mathrm{PbTp}^{\prime}(\mathrm{Hdmpz})_{3} \cdots \mathrm{Cl}\right](\mathrm{Hdmpz}=3,5-$ dimethylpyrazole; $\mathrm{Tp}^{\prime}=$ hydrotris(3,5-dimethylpyrazolyl)borate), obtained as a low-yield product of the reaction of $\mathrm{Pb}\left(\mathrm{NO}_{3}\right)_{2}, \mathrm{P}(\mathrm{O})(\mathrm{dmpz})_{3}, \mathrm{HCl}$ and $\mathrm{KTp}^{\prime}$, containing a structurally similar motif (Fig. 1, B). ${ }^{13}$ In 1995, a review by Parkin on $\mathrm{Tp}$ derivatives included a section on receptors for anions that featured only these two examples. ${ }^{11}$

In 2002, Liu, Kilner and Halcrow reported that the reaction of 3(5)-tert-butylpyrazole with zinc chloride afforded $\left[\mathrm{ClZn}\left(\mathrm{H}^{t} \mathrm{Bupz}\right)_{3} \cdots \mathrm{Cl}\right]$, consisting of the tetrahedral cationic complex $\left[\mathrm{ClZn}\left(\mathrm{H}^{t} \mathrm{Bupz}\right)_{3}\right]^{+}$binding the chloride guest through the three $\mathrm{N}-\mathrm{H}$ groups (Fig. 1, C). ${ }^{14}$

Compounds A, B and $\mathbf{C}$ (Fig. 1) contain a chloride anion bonded to a $\left[\mathrm{L}_{n} \mathrm{M}(\mathrm{Hpz})_{3}\right]^{n+}(\mathrm{Hpz}=$ generic pyrazole $)$ host through a combination of electrostatic attraction and hydrogen bonding. Since anionic Tp ligands (the most widely used within the scorpionate family) bind cationic or neutral Lewis-acidic metal centers, ${ }^{9}$ whereas cationic $\left[\mathrm{L}_{n} \mathrm{M}(\mathrm{Hpz})_{3}\right]^{n+}$ fragments bind anions, these $\left[\mathrm{L}_{n} \mathrm{M}(\mathrm{Hpz})_{3}\right]^{n+}$ complexes can be thought of as anti-scorpionates.
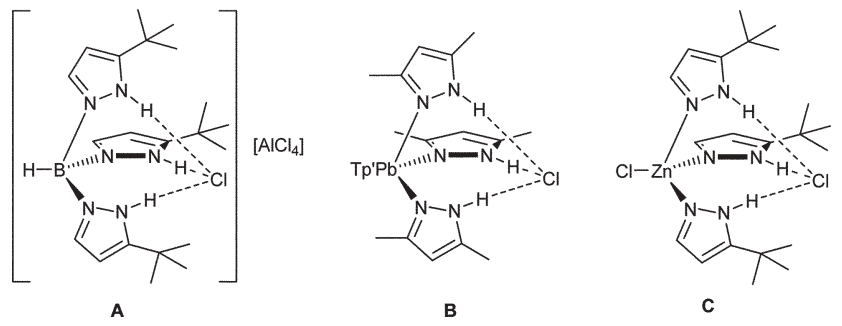

Fig. 1 Structurally characterized tris(pyrazole) anion adducts.
The synthesis of $\mathbf{A}, \mathbf{B}$ and $\mathbf{C}$ did not result from the addition of chloride to a preformed host; rather, compounds $\mathbf{A}, \mathbf{B}$ and $\mathbf{C}$ are self-assembled adducts. If a synthetic route to the chloridefree $\left[\mathrm{L}_{n} \mathrm{M}(\mathrm{Hpz})_{3}\right]^{n+}$ host could be devised, then its behavior toward chloride and other anions could be studied, including the measurement of the strength of the host-guest interaction. To do so, it would be desirable to have a low-interacting anion as counter-anion of the cationic host, making the host $\cdots$ counter-anion interaction negligible compared with the host $\cdots$ anionic guest interaction. Halcrow and co-workers succeeded in the preparation of several $\left[\mathrm{ClZn}\left(\mathrm{H}^{t} \mathrm{Bupz}\right)_{3} \cdots \mathrm{X}\right]$ compounds by reaction of $\left[\mathrm{ClZn}\left(\mathrm{H}^{t} \mathrm{Bupz}\right)_{3} \cdots \mathrm{Cl}\right]$ with the appropriate silver salts, including those in which $\mathrm{X}$ is a weakly coordinating $\mathrm{PF}_{6}{ }^{-15}$, or carbaboranes. ${ }^{16}$ However, these zinc compounds are labile, as the $\mathrm{Zn}$-pyrazole bonds are easily cleaved both by donor solvents and external anions.

Inspired by the appealing structures of the $\left[\mathrm{L}_{n} \mathrm{M}(\mathrm{Hpz})_{3} \cdots \mathrm{Cl}\right]$ adducts reported by the groups of Parkin, Reger and Halcrow, we set up to synthesize stable $\left[\mathrm{L}_{n} \mathrm{M}(\mathrm{Hpz})_{3}\right]^{+}$hosts as their salts of a non-competitive counter-anion.

\section{The choice of counter-anion}

Cationic compounds add electrostatic attraction to other noncovalent interactions at work and therefore lead to stronger overall host-guest complexation. But cationic hosts pose an interesting problem: the counter-anion undergoes the coulombic attraction of the host. Other non-covalent interactions displayed by the host, such as hydrogen bonding, are also exerted to some extent upon the counter-anion. The result is that the counter-anion competes against the external guest for the interaction with the host. To minimize this interference, large counter-anions, in which the charge is largely delocalized, and that are devoid of good hydrogen bond donor groups, are usually chosen, such as tetrafluoroborate $\left(\mathrm{BF}_{4}{ }^{-}\right)$or hexafluorophosphate $\left(\mathrm{PF}_{6}{ }^{-}\right)$. In some cases, these anions have been found to display significant interactions with the host. Thus, in the solid state, crystallographically characterized hydrogenbonded adducts include the one formed between one of the tetrafluoroborate anions and the dicationic bis(pyrazole) complex in the compound $\left[\mathrm{Pt}(\mathrm{dppe})(\mathrm{Hpz})_{2}\right]\left[\mathrm{BF}_{4}\right]_{2}$, reported by Bandini, Banditelli and Bovio (D, Fig. 2) ${ }^{17}$ and those formed between either tetrafluoroborate, arylsulfonate or triflate anions and cationic bis(pyrazole) silver or gold complexes (e.g. in Fig. 2, E) recently reported by Cano and co-workers. $^{7 b}$
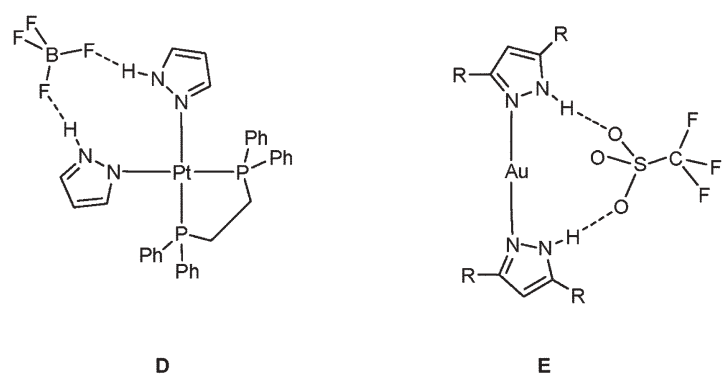

Fig. 2 Hydrogen bond interactions found in the solid state between $\mathrm{BF}_{4}^{-}$(D) or triflate (E) anions and metal complexes. 
Regarding the solution behavior, since electrostatic attractions are non-directional, hosts based only in electrostatic attractions are inherently non-selective. Moreover, this lack of selectivity between different anions includes the counter-anion. And, since the measured, effective binding constant reflects the difference between the host-guest interaction and the hostcounter-anion interaction, a small difference between them results in a low effective binding constant for external anions. As an example, competition between the $\mathrm{PF}_{6}{ }^{-}$counter-anion and the external anionic guest has been invoked by Steed and co-workers as a possible explanation for the fact that a Ru-based monocationic host is not only more selective, but also exhibits higher binding constants, than Pd- or Pt-based dicationic hosts featuring similar hydrogen-bonding groups. ${ }^{6 a}$

Another limitation of the anions customarily employed as counter-anions of cationic hosts is their reactivity. Thus, hydrolysis of $\mathrm{PF}_{6}{ }^{-}$to difluorophosphate in the presence of traces of water has been well documented in organometallic chemistry, ${ }^{18}$ including some example of metal-based anion hosts. ${ }^{6 a}$ An example of hydrolysis of $\mathrm{BF}_{4}{ }^{-}$to boric acid has been reported by Chaudhuri and co-workers to occur during the attempted synthesis of a metal-organic hybrid material. ${ }^{19}$ In organometallic chemistry, such behavior, in addition to the growing number of examples of "non-coordinating anions" acting as ligands or as fluoride-transfer agents, prompted the search for more inert and less coordinating anions. ${ }^{20}$ Tetraphenylborate is known to undergo $\mathrm{B}-\mathrm{C}$ bond cleavage in the presence of strong electrophiles, to coordinate to metal centers $^{20 b}$ and, in the realm of supramolecular chemistry, to interact significantly with organic cations containing $\mathrm{N}-\mathrm{H}$ bonds. ${ }^{21}$ In contrast, it has been found that the presence of the two strongly electron-withdrawing $\mathrm{CF}_{3}$ groups at the 3 and 5 positions of each aromatic ring deactivates the tetraarylborate toward $\mathrm{B}-\mathrm{C}$ cleavage and makes $\mathrm{BAr}^{\prime}{ }_{4}{ }^{-}$one of the most inert and less coordinating anions. ${ }^{4,20 b}$ On the other hand, its lipophilic character confers to its salts a high solubility in moderately polar organic solvents, facilitating spectroscopic studies in these media. Due to these desirables features, $\mathrm{BAr}^{\prime}{ }_{4}^{-}$ has become quite popular in organometallic chemistry and catalysis; for the same reasons, we have chosen it as the counter-anion for our cationic hosts. From among the several ways to introduce the $\mathrm{BAr}^{\prime}{ }_{4}^{-}$counter-anion, we have preferred the reaction of triflato complexes (in turn easily available from chloro or bromo complexes and commercially available AgOTf) with the easily synthesized, thermally stable $\mathrm{NaBAr}_{4}{ }_{4}$ salt. $^{4}$

\section{The choice of metal fragment}

To be able to converge toward an external guest, three pyrazole ligands must be in adjacent positions within the metal coordination sphere. For an octahedral metal complex (the most commonly encountered geometry), this means the fac isomer. Which geometry, fac or mer, is preferred for octahedral complexes $\left[\mathrm{M}(\mathrm{Hpz})_{3} \mathrm{~L}_{3}\right]$, depends dramatically on the nature of the ancillary ligands L. For instance, structurally characterized octahedral $\left[\mathrm{MCl}_{3}(\mathrm{Hpz})_{3}\right]$ complexes are mer isomers. $^{22}$ In contrast, octahedral $\left[\mathrm{M}(\mathrm{CO})_{3} \mathrm{~L}_{3}\right]$ complexes $(\mathrm{L}=$ planar $\mathrm{N}$-donor heterocycles such as pyridines or

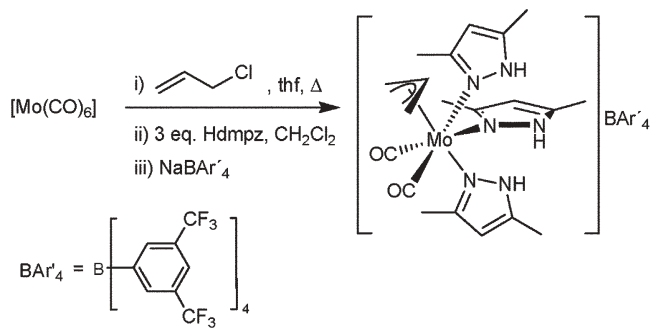

Scheme 1 Synthesis of $\left[\mathrm{Mo}\left(\eta^{3}\right.\right.$-allyl $\left.)(\mathrm{CO})_{2}(\mathrm{Hdmpz})_{3}\right] \mathrm{BAr}^{\prime}{ }_{4}$.

azoles) occur exclusively as the fac isomers (the less sterically encumbered mer isomer is thermodynamically favored for bulky L, such as phosphines). Therefore, a metal carbonyl fragment seemed to be a good choice. Compounds of the metals in groups 6 and 7 include a plethora of heteroleptic complexes containing both $\mathrm{CO}$ and nitrogen heterocycles as ligands. The compound $f a c-\left[\mathrm{Mo}(\mathrm{CO})_{3}(\mathrm{Hpz})_{3}\right]$ was known, ${ }^{23}$ however, like many $\left[\mathrm{Mo}(\mathrm{CO})_{3} \mathrm{~L}_{3}\right]$ complexes ( $\mathrm{L}=$ monodentate $\mathrm{N}$-donor), it is unstable in the air, the yellow powder turning violet in a few hours. Seven-coordinate tris(pyrazole) Mo(II) carbonyl complexes were also known to be unstable, decomposing during attempts to run ${ }^{13} \mathrm{C} N M R$ spectra. ${ }^{24}$ We knew from previous work that pseudo-octahedral $\mathrm{N}$-donor derivatives of the $\left\{\mathrm{Mo}\left(\eta^{3}\right.\right.$-allyl $\left.)(\mathrm{CO})_{2}\right\}$ fragment are usually quite stable, and that cationic complexes within this family are readily accessible, ${ }^{25}$ so we targeted the new $\left[\mathrm{Mo}\left(\eta^{3} \text {-allyl }\right)(\mathrm{CO})_{2}(\mathrm{Hpz})_{3}\right]^{+}$complex. Compounds $\left[\mathrm{Mo}\left(\eta^{3}-\right.\right.$ allyl $\left.) \mathrm{X}(\mathrm{CO})_{2}(\mathrm{NCMe})_{2}\right](\mathrm{X}=\mathrm{Cl}, \mathrm{Br})$ have been the typical starting materials for the synthesis under mild conditions of $\left\{\mathrm{Mo}\left(\eta^{3}\right.\right.$-allyl $\left.)(\mathrm{CO})_{2}\right\} \quad$ species, and neutral $\left[\mathrm{Mo}\left(\eta^{3}-\right.\right.$ allyl $) \mathrm{X}(\mathrm{CO})_{2}(\mathrm{Hpz})_{2}$ ] complexes have been reported by Cotton and Luck, ${ }^{26}$ and by Paredes, Miguel and Villafañe. ${ }^{27}$ However, a nitrile-free route was sought to avoid complications arising from pyrazole-nitrile coupling, a reaction mediated by cationic metal centers, and to which we will refer again below.

Compound $\left[\mathrm{Mo}\left(\eta^{3}\right.\right.$-allyl $\left.)(\mathrm{CO})_{2}(\mathrm{Hdmpz})_{3}\right] \mathrm{BAr}_{4}{ }_{4}(\mathrm{Hdmpz}=$ 3,5-dimethylpyrazole) was synthesized as depicted in Scheme 1 and characterized spectroscopically and by X-ray diffraction, including the hydrogen bonds between the oxygen of a cocrystallized THF solvent molecule and two of the $\mathrm{N}-\mathrm{H}$ pyrazole groups (see Fig. 3, F). ${ }^{28}$
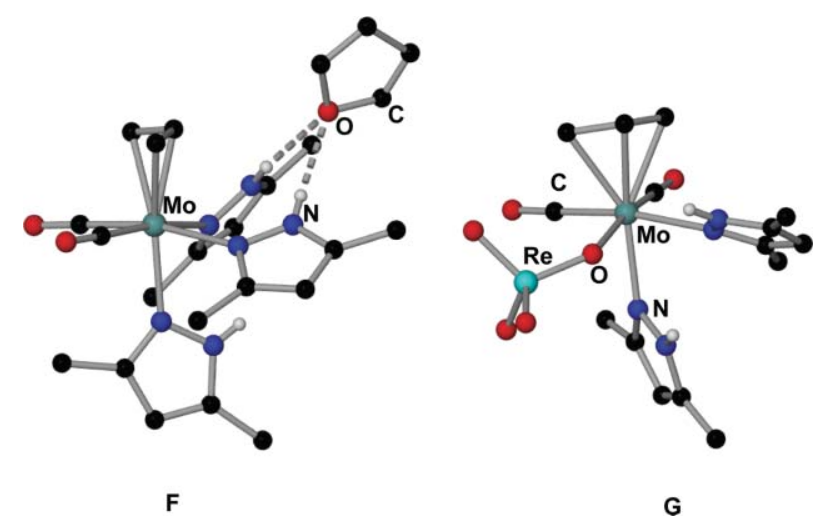

Fig. 3 Molecular structures of $\left[\mathrm{Mo}\left(\eta^{3}\right.\right.$-allyl $\left.)(\mathrm{CO})_{2}(\mathrm{Hdmpz})_{3}\right] \mathrm{BAr}^{\prime}{ }_{4}$. $[\mathrm{THF}]$ (F) (anion not shown) and $\left[\mathrm{Mo}\left(\eta^{3}\right.\right.$-allyl $)\left(\mathrm{OReO}_{3}\right)(\mathrm{CO})_{2^{-}}$ $\left.(\mathrm{Hdmpz})_{2}\right](\mathbf{G})$. 
In solution, the ${ }^{1} \mathrm{H}$ NMR spectrum indicated that the cationic complex was rigid, with a structure like that found in the solid state, with two equivalent pyrazoles each trans to one of the CO ligands, and the third, non-equivalent pyrazole trans to the allyl group. The fact that the two methyl groups on the positions 3 and 5 of each pyrazole ring appear as nonequivalent in the ${ }^{1} \mathrm{H}$ NMR spectrum showed that the pyrazole ligands are not undergoing fast dissociation-coordination equilibrium. However, anions $\left(\mathrm{X}^{-}\right)$, even poorly nucleophilic ones, such as perrhenate, instantaneously substituted one of the pyrazole ligands, affording neutral $\left[\mathrm{Mo}\left(\eta^{3}\right.\right.$-allyl $) \mathrm{X}(\mathrm{CO})_{2^{-}}$ $\left.(\mathrm{Hdmpz})_{2}\right]$ complexes. The structure of $\left[\mathrm{Mo}\left(\eta^{3}\right.\right.$-allyl $)\left(\mathrm{OReO}_{3}\right)$ $(\mathrm{CO})_{2}(\mathrm{Hdmpz})_{2}$, determined by X-ray diffraction, is shown in Fig. 3, G.

A relatively easy substitution of pyrazole by chloride at a Mo(II) carbonyl complex has been noted as early as in 1977 by King and Chen. ${ }^{29}$ These authors reported that $\left[\mathrm{Mo}\left(\eta^{5}\right.\right.$ $\left.\mathrm{Cp})(\mathrm{CO})_{2}(\mathrm{Hpz})_{2}\right] \mathrm{Cl}$ liberate pyrazole and $\left[\mathrm{Mo}\left(\eta^{5}-\mathrm{Cp}\right) \mathrm{Cl}(\mathrm{CO})_{2^{-}}\right.$ $(\mathrm{Hpz})]$ in minutes, while for the more inert tungsten analog, the process was found to take hours. In contrast, $\left[\mathrm{Mo}\left(\eta^{5}-\mathrm{Cp}\right)\right.$ $\left.(\mathrm{CO})_{2}(\mathrm{Hpz})_{2}\right] \mathrm{PF}_{6}$ was stable, due to the low nucleophilicity of hexafluorophosphate.

In view of the foregoing, we turned our attention to the previously unknown $\left[\mathrm{M}(\mathrm{CO})_{3}(\mathrm{Hpz})_{3}\right]^{+}(\mathrm{M}=\mathrm{Mn}, \mathrm{Re})$ complexes, because the $\mathrm{d}^{6}$ configuration should contribute to their stability. To our delight, the high yield syntheses of the $\mathrm{BAr}^{\prime}{ }_{4}{ }^{-}$salts of these new compounds were straightforward from the neutral triflato pentacarbonyl complexes as shown in Scheme $2 .^{30}$

Compounds $\left[\mathrm{M}(\mathrm{CO})_{3}(\mathrm{Hpz})_{3}\right] \mathrm{BAr}^{\prime}{ }_{4}$ were found to be stable toward air and moisture, and their solution IR and NMR spectra showed them to occur exclusively as the fac isomers. Their NMR spectra indicated that, even in donor solvents such as acetonitrile, the cationic complexes do not undergo fast dissociation/re-coordination of their pyrazole ligands.

The manganese compounds were found to be labile toward substitution by all tested anions (e.g. one of such substitution products has been crystallographically characterized, and its structure, showing that the nitrate anion has displaced one pyrazole ligand, which interacts through hydrogen bonds with the resulting nitrate Mn complex is displayed in Fig. 4) but the less nucleophilic perrhenate and perchlorate, ${ }^{30 c}$ whereas the
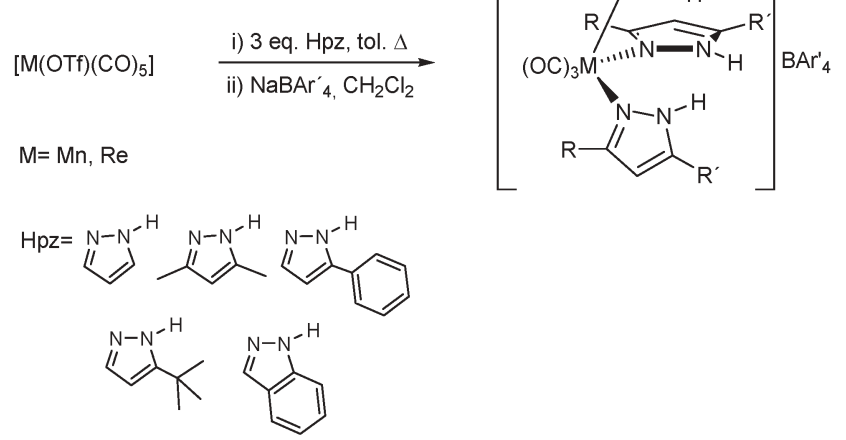

Scheme 2 Synthesis of $f a c-\left[\mathrm{M}(\mathrm{CO})_{3}(\mathrm{Hpz})_{3}\right] \mathrm{BAr}^{\prime}{ }_{4}$ compounds.

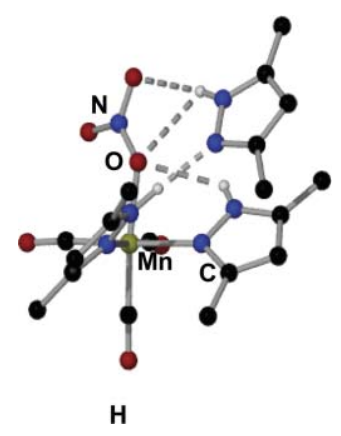

Fig. 4 Molecular structure of the $\left[\mathrm{Mn}\left(\mathrm{ONO}_{2}\right)(\mathrm{CO})_{3}(\mathrm{Hdmpz})_{3}\right]$. [Hdmpz] adduct.

rhenium complexes proved to be sufficiently stable in most cases (see below). Therefore, most of our work focused on the rhenium compounds.

\section{Tris(pyrazole) compounds: solid-state structures}

Several $\left[\mathrm{M}(\mathrm{CO})_{3}(\mathrm{Hpz})_{3}\right] \cdot[\mathrm{X}]\left(\mathrm{M}=\mathrm{Mn}, \mathrm{Re} ; \mathrm{X}=\mathrm{NO}_{3}{ }^{-}\right.$or $\left.\mathrm{ReO}_{4}{ }^{-}\right)$salts were crystallized from mixtures of $\left[\mathrm{M}(\mathrm{CO})_{3}{ }^{-}\right.$ $\left.(\mathrm{Hpz})_{3}\right] \mathrm{BAr}^{\prime}{ }_{4}$ compounds and $\left[\mathrm{BuN}_{4}\right][\mathrm{X}]$ salts, and their structures were determined by X-ray diffraction (see Fig. 5). ${ }^{30 b, c}$ Most of these crystallizations involve anion exchange, as the salts of the metal complexes crystallized separately from $\left[\mathrm{BuN}_{4}\right]\left[\mathrm{BAr}_{4}^{\prime}\right]$. The crystals obtained from the equimolar mixture of $\left[\mathrm{Mn}(\mathrm{CO})_{3}\left(\mathrm{H}^{t} \mathrm{Bupz}\right)_{3}\right] \mathrm{BAr}^{\prime}{ }_{4}$ and $\left[\mathrm{BuN}_{4}\right]\left[\mathrm{ReO}_{4}\right]$ (Fig. 5, L) are an exception as they contained the four ions. ${ }^{30 c}$ The structure of the acetone adduct $\left[\mathrm{Re}(\mathrm{CO})_{3}(\mathrm{Hdmpz})_{3}\right] \mathrm{BAr}_{4}{ }_{4}$. $\left(\mathrm{O}=\mathrm{C}\left(\mathrm{CH}_{3}\right)_{2}\right)$ was also determined (Fig. 5, I) ${ }^{30 b}$ In every instance, and in contrast with structures $\mathbf{A}, \mathbf{B}$ and $\mathbf{C}$ (see above, Fig. 1), two (and not three) ligated pyrazoles of each cationic complex converge toward one of the oxygen atoms of the host, whereas (for the nitrate or perrhenate salts) the third pyrazole forms a hydrogen bond with another anion. The same feature was found in the THF adduct of $\left[\mathrm{Mo}\left(\eta^{3}\right.\right.$-allyl $)(\mathrm{CO})_{2}$ $\left.(\mathrm{Hdmpz})_{3}\right]_{\mathrm{BAr}}{ }_{4}$ (F, Fig. 3) mentioned above. ${ }^{28}$ As the same arrangement is found for $\mathrm{Mn}$ and Re compounds (with largely different metal radii), for hydrogen bond adducts of anions with different shapes (nitrate or perrhenate) and neutral molecules (acetone or THF), for several types of pyrazole ligands (3,5-dimethylpyrazole or 3(5)-tert-butylpyrazole), and for solids with very different lattices (with or without the $\mathrm{BuN}_{4}{ }^{+}$and $\mathrm{BAr}_{4}{ }_{4}^{-}$ions), it must be a result of the geometry of the metal complex, the one feature our compounds have in common and in which they differ from $\mathbf{A}, \mathbf{B}$ and $\mathbf{C}$. An inspection of the metrical data of those structures determined with sufficient accuracy allowed us to propose an explanation of the difference: in $\left[\operatorname{Re}(\mathrm{CO})_{3}\left(\mathrm{H}^{t} \mathrm{Bupz}\right)_{3}\right] \mathrm{BAr}{ }_{4}$ the $\mathrm{N}-\mathrm{Re}-\mathrm{N}$ angles are $85.7(2), 84.1(2)$ and $83.5(2)^{\circ}$, whereas in $\left[\operatorname{Re}(\mathrm{CO})_{3^{-}}\right.$ $\left.\left(\mathrm{H}^{t} \mathrm{Bupz}\right)_{3}\right] \cdot\left[\mathrm{NO}_{3}\right]$ (Fig. 5, K) these angles are 83.9(1), 83.5(1) and $92.1(1)^{\circ}$. The latter (and wider) angle corresponds to the two pyrazole ligands forming hydrogen bonds toward the same nitrate oxygen. The same pattern is apparent when the structures of $\left[\operatorname{Re}(\mathrm{CO})_{3}(\mathrm{Hdmpz})_{3}\right] \mathrm{BAr}_{4}{ }_{4}(\mathrm{~N}-\mathrm{Re}-\mathrm{N}=84.0(3)$, $87.3(2)$ and $\left.84.1(2)^{\circ}\right)$ and its acetone adduct $(\mathrm{N}-\mathrm{Re}-\mathrm{N}=$ $84.1(1), 85.7(2)$ and $90.3(1)^{\circ}$, the latter angle corresponds to 

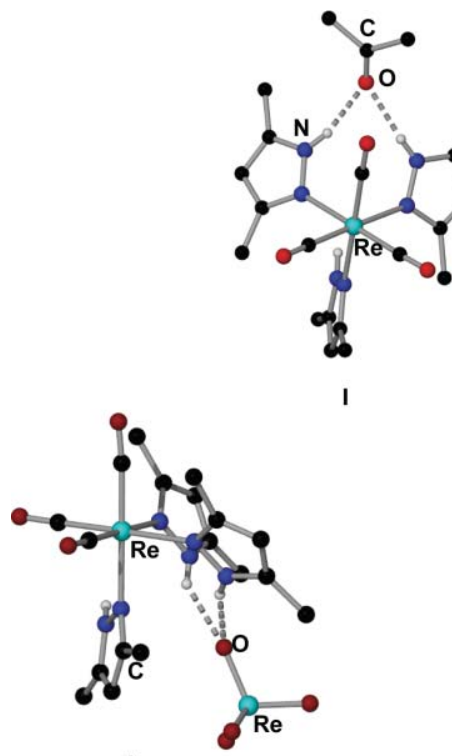

$\mathbf{J}$
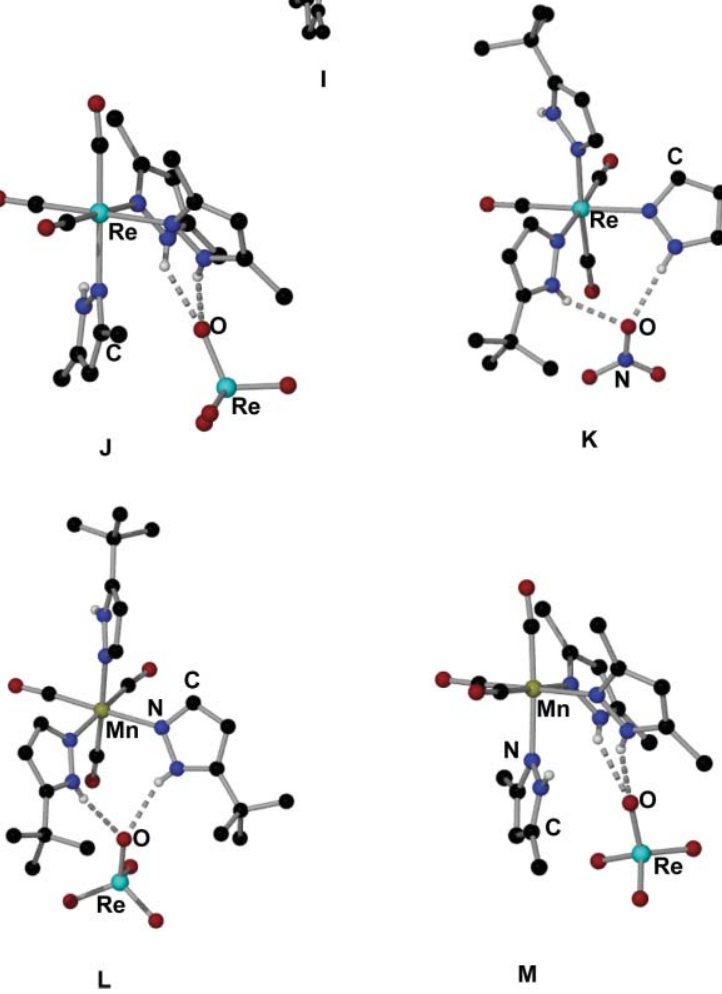

M

Fig. 5 Molecular structures of several $\left[\mathrm{M}(\mathrm{CO})_{3}(\mathrm{Hpz})_{3}\right] \cdot[\mathrm{X}]$ adducts.

the two pyrazoles involved in hydrogen bonds to the acetone oxygen) are compared. This suggest that the formation of the strongly directional hydrogen bonds between the $\mathrm{N}-\mathrm{H}$ groups of two pyrazoles and the anionic or polar guest requires an opening of the $\mathrm{N}-\mathrm{Re}-\mathrm{N}$ angle. Since the minimal cation-anion hydrogen bond interaction occurs for the low interacting $\mathrm{BAr}_{4}^{\prime}$ anion, the $\mathrm{N}-\mathrm{Re}-\mathrm{N}$ angles found in $\mathrm{BAr}_{4}{ }_{4}$ salts can be regarded as the closest to the "natural" angles dictated by the geometrical preferences of the cationic complex. Therefore, the angle widening found in the acetone or nitrate adducts would be a distortion from these preferences, the resulting destabilization being compensated by guest binding. Note that the coordination geometry for the $\mathbf{A}$ and $\mathbf{C}$ compounds mentioned above is approximately tetrahedral about the central atom (B or $\mathrm{Zn}$ ) and thus the natural angles would be much larger than those in our approximately octahedral compounds. As for compound $\mathbf{B}$, although the central lead atom is hexacoordinate, its geometry is far from octahedral, $\mathrm{N}-\mathrm{Pb}-\mathrm{N}$ angles being $111.8(3)^{\circ}$.

Therefore, we hypothesized that guest binding through the $\mathrm{N}-\mathrm{H}$ groups of the three pyrazoles of our octahedral compounds would be unfavorable due to the large distortion that it would require, for which guest binding would not pay off. Indeed, the $\mathrm{Re}-\mathrm{N}$ bond lengths in $\left[\operatorname{Re}(\mathrm{CO})_{3}(\mathrm{Hdmpz})_{3}\right]$ $\mathrm{BAr}^{\prime} \cdot{ }_{4} \cdot\left[\mathrm{O}=\mathrm{C}\left(\mathrm{CH}_{3}\right)_{2}\right]$ (2.195(4), 2.234(4) and 2.239(4) $\AA$ ) are slightly longer than those in $\left[\operatorname{Re}(\mathrm{CO})_{3}(\mathrm{Hdmpz})_{3}\right] \mathrm{BAr}^{\prime}{ }_{4}$ (2.186(8), 2.195(7) and 2.204(6) $\AA$ ), and the two longer ones correspond to the pyrazoles involved in the hydrogen bonding, suggesting that the distortion in the geometry due to guest binding results in loss of orbital overlap and thus in weaker bonds and longer distances. One could expect that these differences in bond lengths should be more pronounced for an anionic guest than for acetone. However, the differences between $\mathrm{Re}-\mathrm{N}$ bond lengths in $\left[\mathrm{Re}(\mathrm{CO})_{3}\left(\mathrm{H}^{t} \mathrm{Bupz}\right)_{3}\right] \mathrm{BAr}^{\prime}{ }_{4}$ (2.178(4), 2.191(4) and 2.193(4) $\AA$ ) and $\left[\operatorname{Re}(\mathrm{CO})_{3}\left(\mathrm{H}^{t} \mathrm{Bupz}\right)_{3}\right]$. $\left[\mathrm{NO}_{3}\right](2.190(3), 2.199(4)$ and $2.234(3) \AA$ ) are lower. Here we must recall that even moderately strong hydrogen bonding can make the azole ligand have some azolate character ${ }^{31}$ and hence to display shorter $\mathrm{M}-\mathrm{N}$ lengths. ${ }^{32}$ The fact that (although the difference is very small) the contrary is found suggests that our hypothesis of a loss of $\mathrm{Re}-\mathrm{N}$ bonding character upon guest binding due to unfavorable $\mathrm{N}-\mathrm{Re}-\mathrm{N}$ angle opening may be correct.

\section{Rhenium tris(pyrazole) compounds: solution behavior}

The behavior of the new tris(pyrazole) rhenium compounds in solution was studied using IR and NMR spectroscopies. ${ }^{30}$ Anion exchange was found to be fast, and binding constants were calculated using ${ }^{1} \mathrm{H}$ NMR titrations for compounds $\left[\operatorname{Re}(\mathrm{CO})_{3}(\mathrm{Hpz})_{3}\right] \mathrm{BAr}_{4}{ }_{4}[\mathrm{Hpz}=$ pyrazole (1), 3,5-dimethylpyrazole (2), 3-phenylpyrazole (3), 3(5)-tert-butylpyrazole (4) and indazole (5)] with several anions (Table 1) in $\mathrm{CD}_{3} \mathrm{CN}$.

The basic fluoride anion deprotonated $\left[\operatorname{Re}(\mathrm{CO})_{3}(\mathrm{Hdmpz})_{3}\right]$ $\mathrm{BAr}_{4}{ }_{4}$, yielding the neutral complex $\left[\operatorname{Re}(\mathrm{dmpz})(\mathrm{CO})_{3^{-}}\right.$ $(\mathrm{Hdmpz})_{2}$, previously reported by Ardizzoia, Masciocchi and co-workers. ${ }^{33}$ Deprotonation by fluoride has been found in many instances, including neutral amide, urea, thiourea and pyrrole derivatives, and it was usually recognized by some drastic change, for instance, in the UV-vis spectrum. ${ }^{34}$ In some cases, distinction between hydrogen bonding and complete $\mathrm{H}^{+}$ transfer may not be easy. In our case, IR spectroscopy was found to be very useful: the $v_{\mathrm{CO}}$ bands of the tris(pyrazole) complex shift a few $\mathrm{cm}^{-1}$ to lower frequencies as a result of hydrogen bonding with anions; e.g., the sharp and intense, $\mathrm{A}_{1}$-symmetric band at higher frequency shifts $3 \mathrm{~cm}^{-1}$ on addition of 1 eq. $\left[\mathrm{Bu}_{4} \mathrm{~N}\right][\mathrm{Cl}]$ to $\left[\operatorname{Re}(\mathrm{CO})_{3}(\mathrm{Hdmpz})_{3}\right] \mathrm{BAr}_{4}{ }_{4}$ in $\mathrm{CH}_{2} \mathrm{Cl}_{2}$; in contrast, a shift of $21 \mathrm{~cm}^{-1}$ results from addition of 1 eq. $\left[\mathrm{Bu}_{4} \mathrm{~N}\right][\mathrm{F}]$, indicating the formation of the neutral deprotonation product. ${ }^{30 b}$ IR spectroscopy indicated partial

Table 1 Binding constants values $\left(K_{\mathrm{a}}, \mathrm{M}^{-1}\right)$ for compounds $\left[\mathrm{Re}(\mathrm{CO})_{3}(\mathrm{Hpz})_{3}\right] \mathrm{BAr}_{4}^{\prime}(\mathbf{1 - 5})$ in $\mathrm{CD}_{3} \mathrm{CN}$

\begin{tabular}{|c|c|c|c|c|c|}
\hline Anion & 1 & 2 & 3 & 4 & 5 \\
\hline $\mathrm{Cl}^{-}$ & $a$ & $6385 \pm 362$ & $2406 \pm 125$ & $4692 \pm 570$ & $320 \pm 6$ \\
\hline $\mathrm{Br}^{-}$ & $540 \pm 27$ & $5593 \pm 198$ & $1712 \pm 90$ & $543 \pm 67$ & $404 \pm 2$ \\
\hline $\mathrm{I}^{-}$ & & $26 \pm 2$ & $80 \pm 1$ & $27 \pm 1$ & $100 \pm 2$ \\
\hline $\mathrm{NO}_{3}{ }^{-}$ & $112 \pm 13$ & $1126 \pm 28$ & $1592 \pm 1$ & $97 \pm 6$ & $295 \pm 2$ \\
\hline $\mathrm{ReO}_{4}{ }^{-}$ & $63 \pm 1$ & $253 \pm 4$ & $67 \pm 9$ & $28 \pm 1$ & $48 \pm 6$ \\
\hline $\mathrm{HSO}_{4}^{-}$ & & & $147 \pm 1$ & $425 \pm 5$ & $141 \pm 6$ \\
\hline
\end{tabular}

${ }^{a}$ Substitution of one pyrazole ligand by the anion. ${ }^{b}$ Decomposition. 
deprotonation of $\left[\mathrm{Re}(\mathrm{CO})_{3}(\mathrm{Hdmpz})_{3}\right] \mathrm{BAr}^{\prime}{ }_{4}$ by the equimolar amount of $\left[\mathrm{Bu}_{4} \mathrm{~N}\right]\left[\mathrm{H}_{2} \mathrm{PO}_{4}\right]$ as the spectrum of the resulting $\mathrm{CH}_{2} \mathrm{Cl}_{2}$ solution showed the bands of both $\left[\operatorname{Re}(\mathrm{CO})_{3}(\mathrm{Hdmpz})_{3}\right] \mathrm{BAr}_{4}{ }_{4}$ and $\left[\operatorname{Re}(\mathrm{dmpz})(\mathrm{CO})_{3}(\mathrm{Hdmpz})_{2}\right]$. Note that $\mathrm{H}^{+}$transfer between $\mathrm{N}$ and $\mathrm{O}$ atoms is typically fast in the NMR timescale, but slow in the IR timescale. ${ }^{35}$

Treatment of $\left[\mathrm{Re}(\mathrm{CO})_{3}(\mathrm{Hdmpz})_{3}\right] \mathrm{BAr}^{\prime}{ }_{4}$ with $\left[\mathrm{Bu}_{4} \mathrm{~N}\right]\left[\mathrm{HSO}_{4}\right]$ afforded, among other non-identified products, a hydrogenbonded adduct between $\mathrm{Hdmpz}$ and the $\left[\mathrm{Re}\left(\mathrm{OSO}_{3}\right)(\mathrm{CO})_{3}\right.$ $(\mathrm{Hdmpz})_{2}$ ] complex, characterized by X-ray diffraction (see Fig. 6, N). Its formation indicates that one of the pyrazoles was protonated by hydrogensulfate, and its place on the metal coordination sphere was occupied by the resulting sulfate anion. Interestingly, $\left[\operatorname{Re}(\mathrm{CO})_{3}\left(\mathrm{H}^{t} \mathrm{Bupz}\right)_{3}\right] \mathrm{BAr}_{4}{ }_{4}$ is stable toward hydrogensulfate, a fact attributed to the steric protection exerted by the bulky tert-butyl group.

In the same line, whilst $\left[\operatorname{Re}(\mathrm{CO})_{3}(\mathrm{Hdmpz})_{3}\right] \mathrm{BAr}^{\prime}{ }_{4}$ and $\left[\operatorname{Re}(\mathrm{CO})_{3}\left(\mathrm{H}^{t} \mathrm{Bupz}\right)_{3}\right] \mathrm{BAr}_{4}{ }_{4}$ are stable in the presence of excess $\left[\mathrm{Bu}_{4} \mathrm{~N}\right][\mathrm{Cl}],\left[\operatorname{Re}(\mathrm{CO})_{3}(\mathrm{Hpz})_{3}\right] \mathrm{BAr}^{\prime}{ }_{4}$ undergoes substitution of one of the pyrazoles by chloride. ${ }^{30 b}$

In solution, at room temperature, the ${ }^{1} \mathrm{H}$ NMR spectra of $\left[\operatorname{Re}(\mathrm{CO})_{3}(\mathrm{Hpz})_{3}\right] \cdot[\mathrm{X}]$ compounds feature only one set of pyrazole signals, indicating the equivalence of the three pyrazoles. However, at low temperature, these signals resolve into a $2: 1$ pattern consistent with anion binding by the $\mathrm{N}-\mathrm{H}$ groups of two pyrazoles, as found in the solid state. ${ }^{30 b}$

To assess the effect of the third pyrazole on the magnitude of the host-guest interaction, we set out to prepare compounds fac, cis- $\left[\operatorname{Re}(\mathrm{CO})_{3}(\mathrm{Hdmpz})_{2} \mathrm{~L}\right] \mathrm{BAr}^{\prime}{ }_{4}(\mathrm{~L}=$ ligand devoid of a hydrogen bond donor group) and to compare their binding constants with those of the tris(pyrazole) compounds. ${ }^{30 c} \mathrm{We}$ first targeted compounds with $\mathrm{L}=1,3,5$-trimethylpyrazole, since this ligand would be a close mimic of the steric and electronic properties of 3,5-dimethylpyrazole. However, all our attempts to prepare this compound in a pure form failed. This was also the case with $N$-methylimidazole. Compounds cis- $\left[\operatorname{Re}(\mathrm{CO})_{4}(\mathrm{Hdmpz})_{2}\right] \mathrm{BAr}^{\prime}{ }_{4}$ and fac, cis- $\left[\operatorname{Re}(\mathrm{CO})_{3}(\mathrm{Hdmpz})_{2^{-}}\right.$ (py)]BAr' ${ }_{4}$ (py = pyridine) could be prepared; however, they were found to be unstable toward anions in solution. This shows that sufficient stability requires the right combination of metal, oxidation state, ditopic ligands and ancillary ligands. In our case, this was found for the compound fac,cis$\left[\operatorname{Re}\left(\mathrm{CN}^{t} \mathrm{Bu}\right)(\mathrm{CO})_{3}(\mathrm{Hdmpz})_{2}\right] \mathrm{BAr}_{4}{ }_{4}\left(\mathrm{CN}^{t} \mathrm{Bu}=\right.$ tert-butyl isocyanide), prepared as indicated in Scheme 3, and the X-ray structure of which is shown in Fig. 7. ${ }^{30 c}$

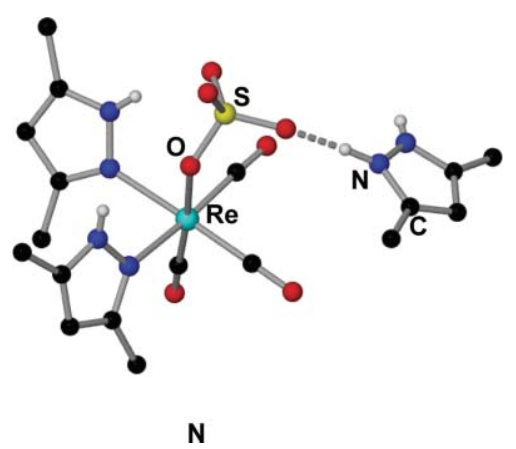

Fig. 6 Molecular structure of $\left[\mathrm{Re}\left(\mathrm{OSO}_{3}\right)(\mathrm{CO})_{3}(\mathrm{Hdmpz})_{2}\right] \cdot\left[\mathrm{H}_{2} \mathrm{dmpz}\right]$.

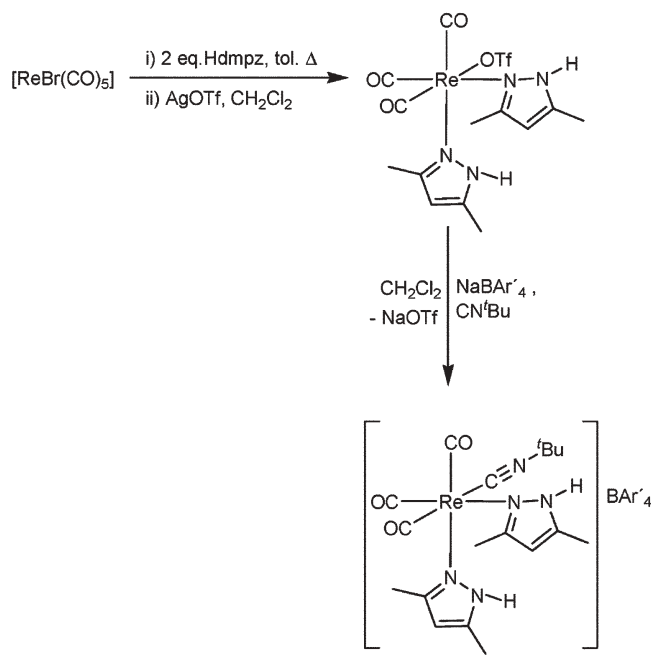

Scheme 3 Synthesis of $\left[\operatorname{Re}(\mathrm{CO})_{3}\left(\mathrm{CN}^{t} \mathrm{Bu}\right)(\mathrm{Hdmpz})_{2}\right] \mathrm{BAr}^{\prime}{ }_{4}$.

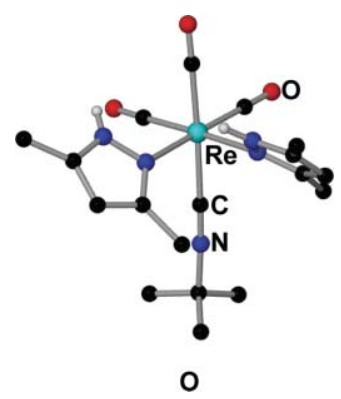

Fig. 7 Molecular structure of $\left[\mathrm{Re}(\mathrm{CO})_{3}\left(\mathrm{CN}^{t} \mathrm{Bu}\right)(\mathrm{Hdmpz})_{2}\right] \mathrm{BAr}{ }_{4}$ (anion not shown).

This compound was found to be stable toward $\mathrm{Bu}_{4} \mathrm{~N}^{+}$salts of chloride, bromide and nitrate, for which fast exchange was found. Binding constants were found to be 1-2 orders of magnitude lower than those calculated for the tris(3,5dimethylpyrazole) compound in the same solvent. Therefore, the presence of a third pyrazole results in stronger binding. We do not think that the difference can be explained by the properties of the $\mathrm{CN}^{t} \mathrm{Bu}$ ligand. Isocyanides are, like $\mathrm{CO}$, strongly $\pi$-acceptors; therefore their presence should make the metal fragment more electron-withdrawing and thus make the pyrazole $\mathrm{N}-\mathrm{H}$ groups stronger hydrogen bond donors. As for the steric properties, the linearity of the isocyanide places the bulky $\mathrm{CN}^{t} \mathrm{Bu}$ group away from the $\mathrm{N}-\mathrm{H}$ groups, where it should not be hindering the anion approach. We speculate that the difference made by the presence of the third pyrazole could be due to a weaker, yet significant interaction in solution between its $\mathrm{N}-\mathrm{H}$ group and the anion.

\section{Pyrazole and pyrazolylamidino ligands}

Metal-mediated coupling of pyrazoles and nitriles to afford pyrazolylamidino ligands (Scheme 4(a)) was first reported in 1986 by McCleverty and co-workers, ${ }^{36}$ and subsequently by a few other groups. ${ }^{37}$ In a collaboration with Arroyo, Villafañe and Miguel, we found that compound $\mathrm{fac}-\left[\mathrm{Re}(\mathrm{CO})_{3^{-}}\right.$ $\left.(\mathrm{Hdmpz})_{2}(\mathrm{NCMe})\right] \mathrm{BAr}_{4}{ }_{4}$ undergoes such coupling, yielding $f a c-\left[\operatorname{Re}(\mathrm{CO})_{3}(\mathrm{Hdmpz})\left(\mathrm{HN}=\mathrm{C}\left(\mathrm{CH}_{3}\right) \mathrm{dmpz}-\kappa^{2} N, N\right)\right] \mathrm{BAr}^{\prime}{ }_{4} \quad($ see 
(a)

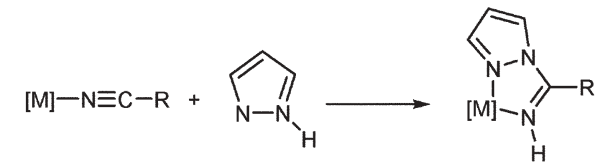

(b)

$$
\left[\operatorname{ReBr}(\mathrm{CO})_{3}(\mathrm{Hdmpz})_{2}\right] \underset{\frac{-\mathrm{AgBr}}{\text { (ii) } \mathrm{NaBAr}_{4}^{\prime}, \mathrm{CH}_{2} \mathrm{Cl}_{2} / \mathrm{MeCN}}}{-\mathrm{NaOTf}^{-\mathrm{AgOTf}}}
$$
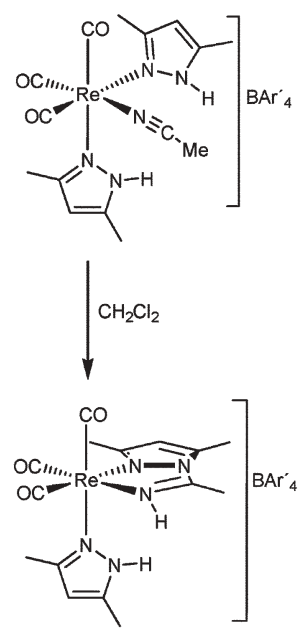

Scheme 4 (a) Formation of a metal-ligated pyrazolylamidino group. (b) Synthesis of $\left[\mathrm{Re}(\mathrm{CO})_{3}(\mathrm{Hdmpz})\left(\mathrm{H} N=\mathrm{C}\left(\mathrm{CH}_{3}\right) \mathrm{dmpz}_{-} \kappa^{2} N, N\right)\right] \mathrm{BAr}_{4}^{\prime}$.

Scheme 4(b)), featuring a bidentate pyrazolylamidino ligand and a monodentate pyrazole ligand, each with a $\mathrm{N}-\mathrm{H}$ group. ${ }^{38}$ In the rigid structure of the cationic complex, both $\mathrm{N}-\mathrm{H}$ groups can converge toward an external anion.

In comparison with the tris(pyrazole) compounds discussed above, now the function of the metal fragment is, in addition to geometrically organize the $\mathrm{N}-\mathrm{H}$ donor groups, to serve as a template that mediates the formation of the pyrazolylamidino ligand. The compound was found to be stable in the presence of different anions; in fact, its $1: 1$ hydrogen bond adducts with chloride (P) and perchlorate $(\mathbf{Q})$ could be characterized by X-ray diffraction (Fig. 8). ${ }^{1} \mathrm{H}$ NMR titrations using the $\mathrm{N}-\mathrm{H}$ signals of both pyrazole and pyrazolylamidino ligands were used to calculate the binding constants shown in Table 2 .

Despite the fact that there are only two $\mathrm{N}-\mathrm{H}$ hydrogen bond donor groups, the binding constant for chloride is relatively large, in agreement with the short $\mathrm{N} \cdots \mathrm{Cl}$ hydrogen bond distances (3.183(7) and 3.184(7) $\AA$ ) found in the solid state. Both the large binding constant and the marked bias for chloride can be attributed to the relatively rigid structure of the
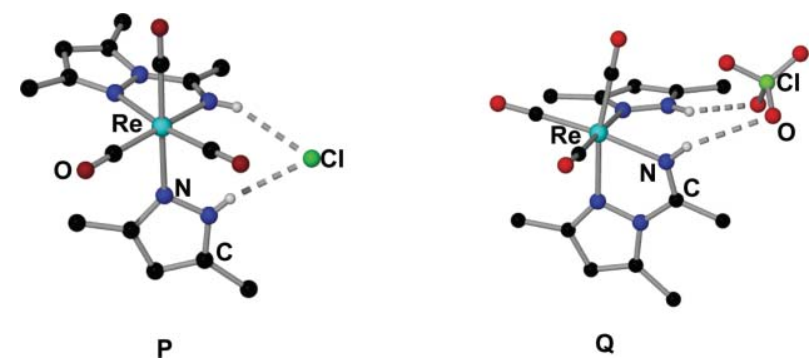

Fig. 8 Molecular structure of $\left[\mathrm{Re}(\mathrm{CO})_{3}(\mathrm{Hdmpz})\left(\mathrm{HN}=\mathrm{C}\left(\mathrm{CH}_{3}\right) \mathrm{dmpz}-\right.\right.$

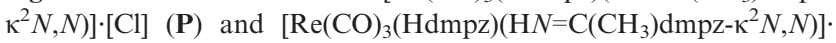
$\left[\mathrm{ClO}_{4}\right](\mathbf{Q})$ adducts.
Table 2 Binding constant values for $\left[\mathrm{Re}(\mathrm{CO})_{3}(\mathrm{Hdmpz})\left(\mathrm{HN}=\mathrm{C}\left(\mathrm{CH}_{3}\right)\right.\right.$ $\left.\left.\mathrm{dmpz}-\kappa^{2} N, N\right)\right] \mathrm{BAr}^{\prime}{ }_{4}$ in $\mathrm{CD}_{3} \mathrm{CN}$

\begin{tabular}{lclr}
\hline Anion & $K_{\mathrm{a}} / \mathrm{M}^{-1}$ & Anion & \multicolumn{1}{c}{$K_{\mathrm{a}} / \mathrm{M}^{-1}$} \\
\hline $\mathrm{Cl}^{-}$ & $8725 \pm 280$ & $\mathrm{NO}_{3}{ }^{-}$ & $521 \pm 26$ \\
$\mathrm{Br}^{-}$ & $1505 \pm 17$ & $\mathrm{ClO}_{4}{ }^{-}$ & $9 \pm 0.4$ \\
$\mathrm{I}^{-}$ & $373 \pm 37$ & & \\
\hline
\end{tabular}

$f a c-\left[\operatorname{Re}(\mathrm{CO})_{3}(\mathrm{Hdmpz})\left(\mathrm{HN}=\mathrm{C}\left(\mathrm{CH}_{3}\right) \mathrm{dmpz}-\kappa^{2} N, N\right)\right]^{+} \quad$ cation; i.e., in comparison with the tris(pyrazole) complexes discussed above, now there is only one free-rotating $\mathrm{Re}-\mathrm{N}$ bond.

\section{Very weak hydrogen bond acceptors: a diamine complex}

The results discussed above suggest that hosts consisting of an appropriate cationic organometallic complex, with a hydrophobic periphery of ancillary ligands, and the $\mathrm{BAr}_{4}{ }^{\prime}$ anion, could allow the detection of even very weak interactions between the complex and an external anion. Non-protonated amines are very weak hydrogen bond donors. Hydrogen bonds between chelated diamines and polar molecules have been proposed to stabilize the transition state in hydrogen transfer to ketones mediated by Noyori-type catalysts ${ }^{39}$ and to determine the nucleobase preferences of anti-cancer Sadler's areneruthenium complexes. ${ }^{40}$ In the solid state, interactions between ethylenediamine (en) $\mathrm{N}-\mathrm{H}$ groups and terephthalate (tph) oxygens link the chains of $[\mathrm{Zn}(\mathrm{en})(\mathrm{tph})]_{\infty}$ polymers, ${ }^{41}$ and those between the $\mathrm{N}-\mathrm{H}$ groups of $\left[\mathrm{Co}(\mathrm{en})_{3}\right]^{3+}$ and the fluoro ligands of $\left[\mathrm{Zr}_{2} \mathrm{~F}_{12}\right]^{4-}$ and $\left[\mathrm{SiF}_{6}\right]^{2-}$ determine the structure of a material with unusual photoelectric properties. ${ }^{42}$ Hydrogen bonds between $\mathrm{N}-\mathrm{H}$ groups of 1,2-phenylenediamine (phda) and the keto oxygens of the ester groups determine the observed conformation of $\left[\mathrm{Mo}(\mathrm{CO})_{2} \mathrm{~L}(\mathrm{phda})\right](\mathrm{L}=$ dimethyl fumarate or maleate) complexes. ${ }^{43}$

As a very simple model where such weak interactions with external anions could be examined isolated from other stronger interactions, we synthesized the new compound $\left[\mathrm{Re}\left(\mathrm{CN}^{t} \mathrm{Bu}\right)(\mathrm{CO})_{3}(\mathrm{phda})\right] \mathrm{BAr}_{4}{ }^{\prime}$ by the reaction sequence displayed in Scheme $5 .^{44}$

The salts $\left[\operatorname{Re}\left(\mathrm{CN}^{t} \mathrm{Bu}\right)(\mathrm{CO})_{3}(\mathrm{phda})\right] \cdot\left[\mathrm{NO}_{3}\right](\mathbf{R}$, Fig. 9; the view in the right shows the pattern of intermolecular hydrogen bonding) and $\left[\operatorname{Re}\left(\mathrm{CN}^{t} \mathrm{Bu}\right)(\mathrm{CO})_{3}(\mathrm{phda})\right] \cdot\left[\mathrm{ClO}_{4}\right]$ (S, Fig. 9; hydrogen bonding between one perchlorate anion and three metal cationic complexes is displayed), prepared by metathesis reactions using $\mathrm{Bu}_{4} \mathrm{~N}^{+}$salts, feature hydrogen bonds between the amine $\mathrm{N}-\mathrm{H}$ groups and the $\mathrm{O}$ atoms of the oxoanions as part of their solid-state structures (see Fig. 9). In $\mathrm{CD}_{3} \mathrm{CN}$ solution, $1: 1$ binding constants ranging from 77(15) (for $\mathrm{Cl}^{-}$)

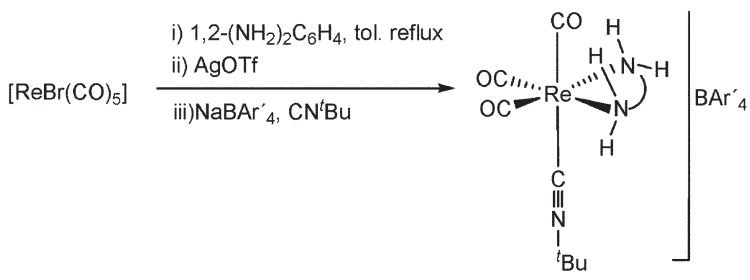

Scheme 5 Synthesis of $\left[\operatorname{Re}(\mathrm{phda})\left(\mathrm{CN}^{t} \mathrm{Bu}\right)(\mathrm{CO})_{3}\right] \mathrm{BAr}_{4}{ }^{\prime}$. 


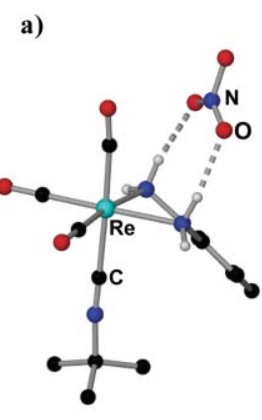

b)

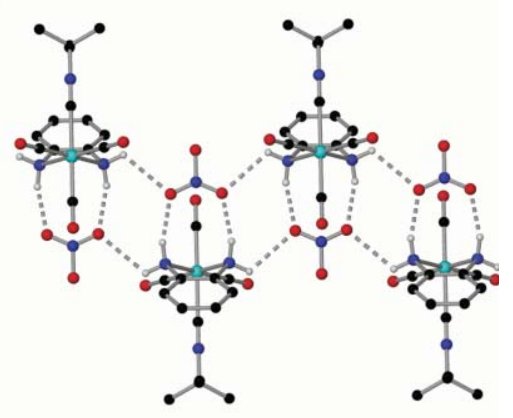

$\mathbf{R}$

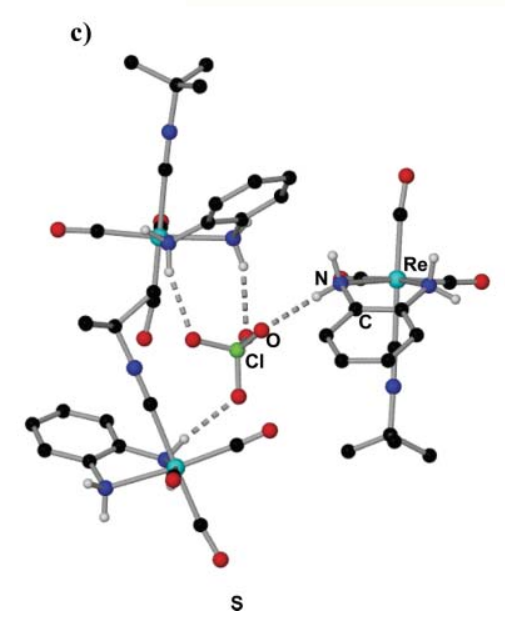

Fig. 9 (a) Molecular structure of the $\left[\mathrm{Re}(\mathrm{phda})\left(\mathrm{CN}^{t} \mathrm{Bu}\right)(\mathrm{CO})_{3}\right] \cdot\left[\mathrm{NO}_{3}\right]$ adduct. (b) View of the zigzag chains formed in the nitrate adduct. (c) Molecular structure of the $\left[\mathrm{Re}(\mathrm{phda})\left(\mathrm{CN}^{t} \mathrm{Bu}\right)(\mathrm{CO})_{3}\right] \cdot\left[\mathrm{ClO}_{4}\right]$ adduct showing the hydrogen bonds between one $\mathrm{ClO}_{4}{ }^{-}$anion and three cationic complexes.

to 18 (3) (for $\mathrm{ClO}_{4}{ }^{-}$) were calculated from the change in the chemical shift of the $\mathrm{N}-\mathrm{H}$ signals as function of the amount of anion added.

\section{Bidentate ditopic ligands: biimidazole}

Biimidazole is another molecule able both to bind a metal center (as a chelate) and to act as a hydrogen bond donor. Strong self-association makes biimidazole quite insoluble; e.g., its low solubility in $\mathrm{CD}_{3} \mathrm{CN}$ makes it NMR-invisible in this solvent. On the other hand, in DMSO- $\mathrm{d}_{6}$, in which biimidazole is sparingly soluble, the chemical shift of its $\mathrm{N}-\mathrm{H}$ signals does not change appreciably on addition of the equimolar amount of $\left[\mathrm{Bu}_{4} \mathrm{~N}\right][\mathrm{Cl}]$, reflecting that the interaction between the $\mathrm{N}-\mathrm{H}$ groups and the anion is very weak. ${ }^{45}$ This can be attributed to a combination of self-association and the unfavorable loss of rotational entropy when the two $\mathrm{N}-\mathrm{H}$ groups of biimidazole form simultaneously hydrogen bonds with a given anion. Chelation of a metal center can have a dramatic effect on biimidazole solubility and on the magnitude of its anion binding. In the resulting complex, the lone electron pairs that acted as hydrogen bond acceptors in free biimidazole are now blocked, being used for metal binding. Therefore, to the extent that the complex is devoid of additional hydrogen-bond acceptor groups, there will be no strong self-association. The loss of rotational entropy of biimidazole would be amply surpassed by the largely favorable metal chelation; thus, using the language of supramolecular chemistry, metal binding would pre-organize biimidazole.

Compared with the complexes of monodentate pyrazoles discussed above, biimidazole chelate complexes should be more stable toward substitution by the anionic guests; hence, a wider range of metal fragments should provide suitable hosts. $\left[\mathrm{Mo}(\mathrm{CO})_{4}(\mathrm{~N}-\mathrm{N})\right]$ and $\left[\mathrm{Mo}\left(\eta^{3}-\operatorname{allyl}\right) \mathrm{Cl}(\mathrm{CO})_{2}(\mathrm{~N}-\mathrm{N})\right](\mathrm{N}-\mathrm{N}=$ diimine) complexes are easily synthesized and relatively stable. ${ }^{46}$ However, the allyl compound and its methallyl analog are very insoluble, presumably due to intermolecular hydrogen bonds between biimidazole $\mathrm{N}-\mathrm{H}$ groups and the $\mathrm{Cl}$ ligand, a good hydrogen-bond acceptor. Compound $\left[\mathrm{Mo}\left(\eta^{3}-\right.\right.$ allyl $) \mathrm{Cl}(\mathrm{CO})_{2}\left(\mathrm{H}_{2}\right.$ biim $\left.)\right]\left(\mathrm{H}_{2}\right.$ biim = biimidazole $)$ suffered from other important limitation: as it was demonstrated by X-ray diffraction, its chloride ligand underwent substitution by bromide (see Fig. 10), and presumably by other anions. To make it worst, such substitution was very difficult to detect, as color, IR and NMR spectra of the chloro and bromo derivatives are very similar.

Less predictably, the tetracarbonyl biimidazole complex was found to be insoluble in organic solvents, including in the highly polar and strong hydrogen-bond acceptor DMSO- $\mathrm{d}_{6}$, to the point of precluding the study of its solution behavior by ${ }^{1} \mathrm{H}$ NMR. This suggests the presence of strong hydrogen bonds between biimidazole $\mathrm{N}-\mathrm{H}$ groups and the oxygen atoms of the carbonyl ligands, and indeed a related interaction has been characterized by X-ray diffraction by Villafañe and co-workers in the very insoluble $c i s-\left[\mathrm{Mo}(\mathrm{CO})_{4}(\mathrm{Hpz})_{2}\right]$ complex. ${ }^{47}$

An obvious way to disrupt the intermolecular hydrogen bonds that we proposed were limiting so severely the solubility of the neutral biimidazole complexes was employing cationic complexes, as cation-cation repulsion and anion interposition would oppose association. At first sight, cation-anion association could lead to an even worst scenario, but we hoped that using $\mathrm{BAr}^{\prime}{ }_{4}^{-}$(see above) would minimize ion pairing. Substitution of chloride by a neutral ligand in $\left[\mathrm{Mo}\left(\eta^{3}-\right.\right.$ allyl $) \mathrm{Cl}(\mathrm{CO})_{2}(\mathrm{~N}-\mathrm{N})$ ] provided an obvious route to the cationic complexes, and $\mathrm{CN}^{t} \mathrm{Bu}$ was found to be ligand of choice (see Scheme 6). ${ }^{46}\left[\mathrm{Mo}\left(\eta^{3}-\right.\right.$ methallyl $\left.)\left(\mathrm{CN}^{t} \mathrm{Bu}\right)(\mathrm{CO})_{2}(\mathrm{~N}-\mathrm{N})\right] \mathrm{BAr}^{\prime}{ }_{4}$ was found to be very soluble in $\mathrm{CH}_{2} \mathrm{Cl}_{2}$, THF and $\mathrm{CD}_{3} \mathrm{CN}$, and stable towards several anions. Unlike halide substitution in the neutral precursor (see above), substitution of monodentate carbonyl or isocyanide ligands in $\left[\mathrm{Mo}\left(\eta^{3}\right.\right.$-methallyl) $\left.\left(\mathrm{CN}^{t} \mathrm{Bu}\right)(\mathrm{CO})_{2}(\mathrm{~N}-\mathrm{N})\right] \mathrm{BAr}^{\prime}{ }_{4}$ by anions would be easily detected by IR, since the $v_{\mathrm{CO}}$ bands of these compounds and those of the potential substitution products would be largely different. Moreover, free $\mathrm{CN}^{t} \mathrm{Bu}$ would be also detected by IR.

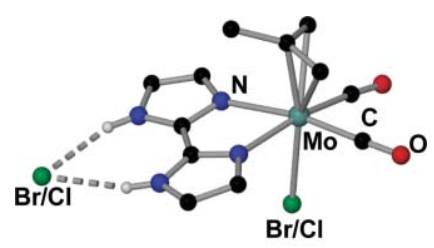

$\mathbf{T}$

Fig. 10 Molecular structure of $\left[\mathrm{Mo}(\mathrm{Cl} / \mathrm{Br})\left(\eta^{3}\right.\right.$-allyl $)(\mathrm{CO})_{2}\left(\mathrm{H}_{2}\right.$ biim $\left.)\right]$. $[\mathrm{Cl} / \mathrm{Br}]$. 


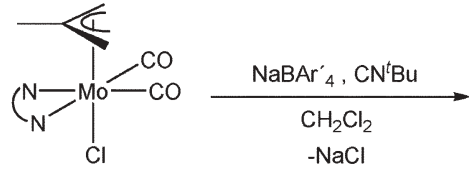

$\mathrm{N}-\mathrm{N}=$ bipy $^{\prime}, \mathrm{H}_{2}$ biim

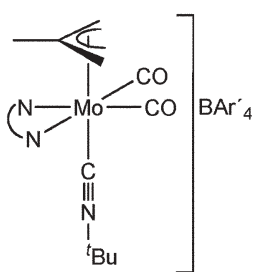<smiles>Cc1ccc(NC(=O)c2ccnc(-c3cc(NC(=O)c4ccc(C)cc4)ccn3)c2)cc1</smiles><smiles>C1CNC(C2NCCN2)N1</smiles>

$\mathrm{H}_{2}$ biim
Scheme 6 Synthesis of $\left[\mathrm{Mo}\left(\eta^{3}-\right.\right.$ methallyl $\left.)(\mathrm{N}-\mathrm{N})(\mathrm{CO})_{2}\left(\mathrm{CN}^{t} \mathrm{Bu}\right)\right] \mathrm{BAr}{ }_{4}$ compounds.

To show that the synthetic scheme used to prepare $\left[\mathrm{Mo}\left(\eta^{3}\right.\right.$ methallyl $\left.)\left(\mathrm{CN}^{t} \mathrm{Bu}\right)(\mathrm{CO})_{2}(\mathrm{~N}-\mathrm{N})\right] \mathrm{BAr}^{\prime}{ }_{4}$ can be easily extended to other $\mathrm{N}-\mathrm{N}$ chelates, an analogous complex of a bis(amido)bipyridine (bipy', see Scheme 6), a type of ligand the chemistry of which has been extensively studied by Beer and co-workers, was similarly prepared, and it was found to be also both stable and highly soluble. ${ }^{46}$ The binding constants in $\mathrm{CD}_{3} \mathrm{CN}$ displayed in Table 3 indicate a strong non-selective interaction with anions for the biimidazole complexes, whereas the more dedicated binding cavity of the bipyridine host leads to a significant bias toward the smaller anions.

The hydrogen bond adducts $\left[\mathrm{Mo}\left(\eta^{3}-\right.\right.$ methallyl)(bipy') $\left.(\mathrm{CO})_{2}\left(\mathrm{CN}^{t} \mathrm{Bu}\right)\right] \cdot\left[\mathrm{HSO}_{4}\right](\mathbf{U})$, $\left[\mathrm{Mo}\left(\eta^{3}-\right.\right.$ methallyl $)\left(\mathrm{H}_{2}\right.$ biim $)(\mathrm{CO})_{2}-$ $\left.\left(\mathrm{CN}^{t} \mathrm{Bu}\right)\right] \cdot[\mathrm{Br}] \quad(\mathbf{V})$ and $\left[\mathrm{Mo}\left(\eta^{3}-\right.\right.$ methallyl $)\left(\mathrm{H}_{2}\right.$ biim $)(\mathrm{CO})_{2}-$ $\left.\left(\mathrm{CN}^{t} \mathrm{Bu}\right)\right] \cdot\left[\mathrm{ReO}_{4}\right](\mathbf{W})$ were crystallographically characterized (see Fig. 11).

A different cationic host based on Ru(biimidazole) was synthesized as shown in Scheme 7, and it was also found to be stable in the presence of several anions. ${ }^{45}$ Despite the presence of a chloride ligand, a potential good hydrogen bond acceptor, it was also found to be very soluble in organic solvents, highlighting the advantages of using cationic complexes in combination with the $\mathrm{BAr}_{4}^{\prime}{ }^{-}$anion.

The structures of the chloride $(\mathbf{X})$ and nitrate $(\mathbf{Y})$ adducts of $\left[\mathrm{RuCl}\left(\eta^{6} \text {-cym }\right)\left(\mathrm{H}_{2} \text { biim }\right)\right]^{+}(\mathrm{cym}=p$-methylisopropylbenzene $)$ were determined by X-ray diffraction (see Fig. 12). Interestingly, for the nitrate adduct, as for $\left[\mathrm{Mo}\left(\eta^{3}\right.\right.$ methallyl $\left.)\left(\mathrm{CN}^{t} \mathrm{Bu}\right)(\mathrm{CO})_{2}(\mathrm{~N}-\mathrm{N})\right] \cdot\left[\mathrm{ReO}_{4}\right]$ (see Fig. 11, W), each biimidazole $\mathrm{N}-\mathrm{H}$ group establishes a hydrogen bond with one

Table 3 Binding constant values $\left(\mathrm{M}^{-1}\right)$ for compounds $\left[\mathrm{Mo}\left(\eta^{3}\right.\right.$ methallyl $\left.)\left(\mathrm{CN}^{t} \mathrm{Bu}\right)(\mathrm{CO})_{2}(\mathrm{~N}-\mathrm{N})\right] \mathrm{BAr}^{\prime}{ }_{4}\left(\mathrm{~N}-\mathrm{N}=\right.$ bipy $^{\prime}, 6 ; \mathrm{H}_{2}$ biim, 7$)$ in $\mathrm{CD}_{3} \mathrm{CN}$

\begin{tabular}{lrc}
\hline Anion & \multicolumn{1}{l}{$\mathbf{l}$} \\
\hline $\mathrm{Cl}^{-}$ & $17169 \pm 1141$ & $11452 \pm 1152$ \\
$\mathrm{Br}^{-}$ & $7183 \pm 277$ & $10496 \pm 681$ \\
$\mathrm{I}^{-}$ & $217 \pm 17$ & $315 \pm 51$ \\
$\mathrm{NO}_{3}{ }^{-}$ & $992 \pm 15$ & $10693 \pm 939$ \\
$\mathrm{HSO}_{4}{ }^{-}$ & $779 \pm 11$ & $10447 \pm 781$ \\
$\mathrm{OAc}^{-}$ & $342 \pm 30$ & $436 \pm 47$ \\
$\mathrm{ReO}_{4}{ }^{-}$ & $25 \pm 9$ & 47 \\
\hline
\end{tabular}

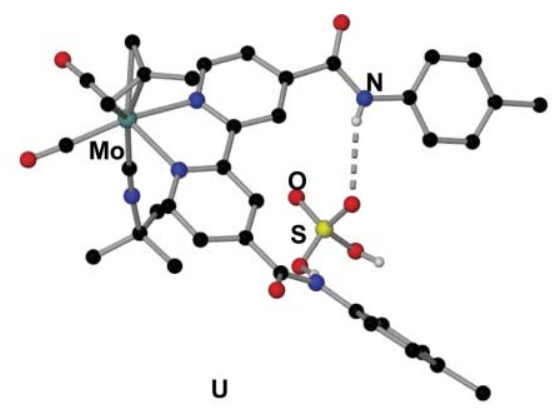

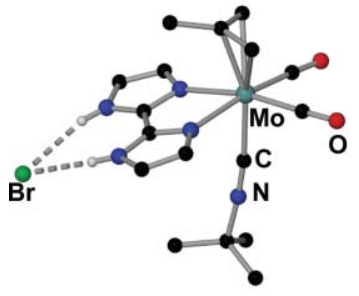

V

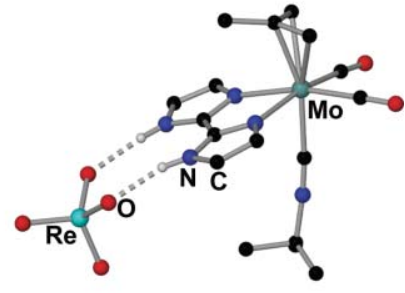

W
Fig. 11 Molecular structure of several $\left[\mathrm{Mo}\left(\eta^{3}-\right.\right.$ methallyl $)(\mathrm{N}-$ $\left.\mathrm{N})(\mathrm{CO})_{2}\left(\mathrm{CN}^{t} \mathrm{Bu}\right)\right] \cdot[\mathrm{X}]$ adducts.

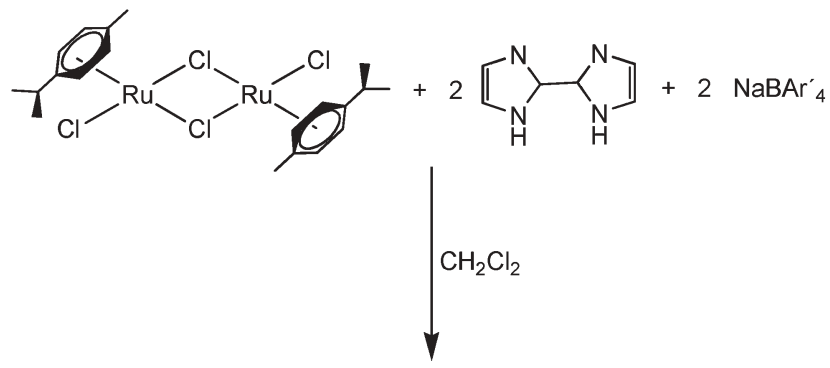<smiles>Cc1ccc(C)c(N2C=CNC2N2CCNC2C(C)(C)C)c1</smiles>

Scheme 7 Synthesis of $\left[\mathrm{RuCl}\left(\eta^{6}-\mathrm{cym}\right)\left(\mathrm{H}_{2}\right.\right.$ biim $\left.)\right] \mathrm{BAr}{ }_{4}$.
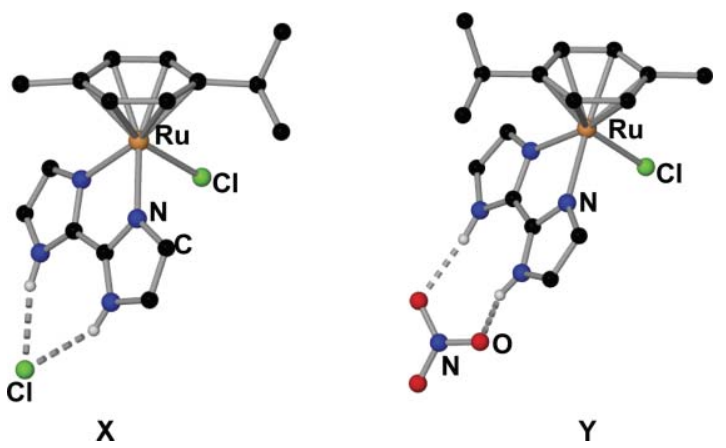

Fig. 12 View of the crystalline structure of the $\left[\mathrm{RuCl}\left(\eta^{6}\right.\right.$-cym $)$ $\left(\mathrm{H}_{2}\right.$ biim $\left.)\right] \cdot[\mathrm{Cl}](\mathbf{X})$ and $\left[\mathrm{RuCl}\left(\eta^{6}-\mathrm{cym}\right)\left(\mathrm{H}_{2}\right.\right.$ biim $\left.)\right] \cdot\left[\mathrm{NO}_{3}\right](\mathbf{Y})$ adducts. 
of the oxygen atoms of the oxoanion, forming a ninemembered ring.

\section{Conclusions}

The simple hosts outlined in this Article achieve relatively strong anion binding through a combination of hydrogen bonding and coulombic attraction. The hydrogen bond donor groups are at the periphery of ligands, the proper orientation of which is provided by their coordination to organometallic fragments. The metal fragment must provide stability to prevent ligand dissociation, even in the presence of the anions, and must lack strong hydrogen bond acceptor groups that, through self-association, would reduce solubility and anion binding strength. Simple monodentate ligands (e.g., pyrazoles) can be used, but then the metal fragment must be carefully chosen, for its geometrical preferences will dictate the geometry of the host. $\mathrm{BAr}_{4}{ }_{4}^{-}$is low interacting and inert, and its salts are very soluble in organic solvents of moderate polarity; therefore, it is an excellent counter-anion for cationic hosts in these media.

\section{Acknowledgements}

We thank our co-workers and collaborators, whose names appear in the references. Support from Ministerio de Ciencia y Tecnología (grant CTQ2006-07036/BQU to J. P.) and European Union (grant UE-05-ERG-516505 to L. R.) are gratefully acknowledged. L. R. thanks the Ministerio de Educación y Ciencia for a Ramón y Cajal contract.

\section{References}

1 (a) P. D. Beer and D. K. Smith, Prog. Inorg. Chem., 1997, 46, 1; (b) P. D. Beer and P. A. Gale, Angew. Chem., Int. Ed., 2001, 40, 486; (c) P. D. Beer and E. J. Hayes, Coord. Chem. Rev., 2003, 240, 167; (d) C. R. Rice, Coord. Chem. Rev., 2006, 250, 3190; (e) J. W. Steed, Chem. Commun., 2006, 2637; (f) M. H. Filby and J. W. Steed, Coord. Chem. Rev., 2006, 250, 3200.

2 J. W. Canary and B. C. Gibb, Prog. Inorg. Chem., 1997, 45, 1.

3 E. Meggers, G. E. Atilla-Gokcumen, H. Bregman, J. Maksimoska, S. P. Mulcahy, N. Pagano and D. S. Williams, Synlett, 2007, 1177.

4 N. A. Yakelis and R. G. Bergman, Organometallics, 2005, 24, 3579.

5 (a) C. R. Bondy, S. J. Loeb and P. A. Gale, Chem. Commun., 2001, 729; (b) C. R. Bondy, P. A. Gale and S. J. Loeb, J. Supramol. Chem., 2002, 2, 93; (c) C. R. Bondy, P. A. Gale and S. J. Loeb, J. Am. Chem. Soc., 2004, 126, 5030; (d) I. El Drubi Vega, P. A. Gale, M. E. Light and S. J. Loeb, Chem. Commun., 2005, 4913.

6 (a) K. J. Wallace, R. Daari, W. J. Belcher, L. O. Abouderbala, M. G. Boutelle and J. W. Steed, J. Organomet. Chem., 2003, 666, 63; (b) D. R. Turner, E. C. Spencer, J. A. K. Howard, D. A. Tocher and J. W. Steed, Chem. Commun., 2004, 1352; (c) D. R. Turner, B. Smith, E. C. Spencer, A. E. Goeta, I. R. Evans, J. A. K. Howard, D. A. Tocher and J. W. Steed, New J. Chem., 2005, 29, 90.

7 (a) S. Trofimenko, Chem. Rev., 1972, 72, 497; (b) M. L. Gallego, P. Ovejero, M. Cano, J. V. Heras, J. A. Campo, E. Pinilla and M. R. Torres, Eur. J. Inorg. Chem., 2004, 3089; (c) I. Ara, J. Forniés, R. Lasheras, A. Martín and V. Sicilia, Eur. J. Inorg. Chem., 2006, 948.

8 (a) M. Tadokoro and K. Nakasuji, Coord. Chem. Rev., 2000, 198, 205; (b) T. Murata, Y. Morita, Y. Nishimura and K. Nakasuji, Polyhedron, 2005, 24, 2625; (c) B.-B. Ding, Y.-Q. Weng, Y. Cui, X.-M. Chen and B.-H. Ye, Supramol. Chem., 2005, 17, 475; (d) R.-L. Sang and L. Xu, Polyhedron, 2006, 25, 2167.

9 S. Trofimenko, Polyhedron, 2004, 23, 197.

10 W. Kläui, M. Berghahn, G. Rheinwald and H. Lang, Angew. Chem., Int. Ed., 2000, 39, 2464.
11 G. Parkin, Adv. Inorg. Chem., 1995, 42, 291.

12 A. Looney, G. Parkin and A. L. Rheingold, Inorg. Chem., 1991, 30, 3099.

13 D. L. Reger, Y. Ding, A. L. Rheingold and R. L. Ostrander, Inorg. Chem., 1994, 33, 4226.

14 X. Liu, C. A. Kilner and M. A. Halcrow, Chem. Commun., 2002, 704.

15 S. L. Renard, C. A. Kilner, J. Fisher and M. A. Halcrow, J. Chem. Soc., Dalton Trans., 2002, 4206.

16 S. L. Renard, A. Franken, C. A. Kilner, J. D. Kennedy and M. A. Halcrow, New J. Chem., 2002, 26, 1634.

17 A. L. Bandini, G. Banditelli and B. Bovio, Polyhedron, 2001, 20, 2869.

18 E. S. Chernyshova, R. Goddard and K.-R. Pörschke, Organometallics, 2007, 26, 3236, and references therein.

19 A. K. Ghosh, D. Ghoshal, E. Zangrando, J. Ribas and N. R. Ray Chaudhuri, Inorg. Chem., 2007, 46, 3057.

20 (a) W. Beck and K. Sünkel, Chem. Rev., 1988, 88, 1405; (b) S. H. Strauss, Chem. Rev., 1993, 93, 927; (c) I. Krossing and I. Raabe, Angew. Chem., Int. Ed., 2004, 43, 2066.

21 S. Kiviniemi, M. Nissinen, T. Alaviuhkola, K. Rissanen and J. Pursiainen, J. Chem. Soc., Perkin Trans. 2, 2001, 2364.

22 (a) A. Albinati, U. E. Bucher, V. Gramlich, O. Renn, H. Ruegger and L. Venanzi, Inorg. Chim. Acta, 1999, 284, 191; (b) S. A. Cotton, V. Franckevicius and J. Fawcett, Polyhedron, 2002, 21, 2055; (c) B. Machura, M. Jaworska and R. Kruszynski, Polyhedron, 2004, 23, 2005; (d) E. Reisner, V. B. Arion, A. Eichinger, N. Kandler, G. Giester, A. J. L. Pombeiro and B. K. Keppler, Inorg. Chem., 2005, 44, 6704; (e) G. W. Cushing, W. A. Howard and K. Pang, J. Mol. Struct., 2006, 797, 165.

23 G. A. Ardizzoia, S. Brenna, G. LaMonica, A. Maspero and N. Masciocchi, J. Organomet. Chem., 2002, 649, 173.

24 P. K. Baker, M. van Kampen, C. Roos and J. Spaeth, Transition Met. Chem., 1994, 19, 165.

25 (a) J. Perez, L. Riera, V. Riera, S. Garcia-Granda and E. GarciaRodriguez, J. Am. Chem. Soc., 2001, 123, 7469; (b) D. Morales, M. E. Navarro Clemente, J. Perez, L. Riera, V. Riera and D. Miguel, Organometallics, 2002, 21, 4934.

26 F. A. Cotton and R. L. Luck, Acta Crystallogr., Sect. C, 1990, 46, 138.

27 P. Paredes, D. Miguel and F. Villafañe, Eur. J. Inorg. Chem., 2003, 995.

28 J. Perez, D. Morales, S. Nieto, L. Riera, V. Riera and D. Miguel, Dalton Trans., 2005, 884.

29 R. B. King and K. Chen, Inorg. Chem., 1977, 16, 3372.

30 (a) S. Nieto, J. Perez, V. Riera, D. Miguel and C. Alvarez, Chem. Commun., 2005, 546; (b) S. Nieto, J. Perez, L. Riera, V. Riera and D. Miguel, Chem.-Eur. J., 2006, 12, 2244; (c) S. Nieto, J. Perez, L. Riera, V. Riera, D. Miguel, J. A. Golen and A. L. Rheingold, Inorg. Chem., 2007, 46, 3407.

31 C. Hu, B. C. Noll, C. E. Schulz and W. R. Scheidt, Inorg. Chem., 2006, 45, 9721.

32 G. Albertin, S. Antoniutti, A. Bacchi, G. Pelizzi and M. Tollon, J. Organomet. Chem., 2005, 690, 4573.

33 G. A. Ardizzoia, G. LaMonica, A. Maspero, M. Moret and N. Masciocchi, Eur. J. Inorg. Chem., 1998, 1503.

34 V. Amendola, D. Esteban-Gómez, L. Fabbrizzi and M. Liccelli, Acc. Chem. Res., 2006, 39, 343.

35 C. Cordier, E. Vauthier, A. Adenier, Y. Lu, A. Massat and A. Cossé-Barbi, Struct. Chem., 2004, 15, 295.

36 C. J. Jones, J. A. McCleverty and A. Rothin, J. Chem. Soc., Dalton Trans., 1986, 109.

37 See footnote 4 of ref. 38.

38 M. Arroyo, D. Miguel, F. Villafañe, S. Nieto, J. Perez and L. Riera, Inorg. Chem., 2006, 45, 7018.

39 (a) R. Noyori and S. Hashiguchi, Acc. Chem. Res., 1997, 30, 97. For an overview of related chemistry, see: $(b) \mathrm{K}$. Muñiz, Angew. Chem., Int. Ed., 2005, 44, 6622; (c) D. B. Grotjahn, Chem.-Eur. J., 2005, 11, 7146.

40 Y. K. Yan, M. Melchart, A. Habtemariam and P. J. Sadler, Chem. Commun., 2005, 4764.

41 G. Guilera and J. Steed, Chem. Commun., 1999, 1563.

42 Y. Du, M. Yang, J. Yu, Q. Pan and R. Xu, Angew. Chem., Int. Ed., 2005, 44, 7988. 
43 C.-H. Lai, C.-H. Cheng, W.-C. Chou and S.-L. Wang, Organometallics, 1993, 12, 1105; C.-H. Lai, C.-H. Cheng, W.-C. Chou and S.-L. Wang, Organometallics, 1993, 12, 3418.

44 S. Nieto, J. Pérez, L. Riera, V. Riera and D. Miguel, New J. Chem., 2006, 30, 838.

45 L. Ion, D. Morales, J. Perez, L. Riera, V. Riera, R. A. Kowenicki and M. McPartlin, Chem. Commun., 2006, 91

46 L. Ion, D. Morales, S. Nieto, J. Perez, L. Riera, V. Riera, D. Miguel, R. A. Kowenicki and M. McPartlin, Inorg. Chem.,
$2007,46,2846$. In these $2,2^{\prime}$-bipyridines, the amido groups are at the $4,4^{\prime}$-positions. It is interesting to note here that in 5,5'-diamido$2,2^{\prime}$-bipyridines, for which the amido groups within each ligand diverge, convergence of $\mathrm{N}-\mathrm{H}$ groups from different ligands toward an anion is made possible by the coordination of several bipy ligands to the same metal center, see: L. H. Uppadine, M. G. B. Drew and P. D. Beer, Chem. Commun., 2001, 291.

47 P. Paredes, M. Arroyo, D. Miguel and F. Villafañe, J. Organomet. Chem., 2003, 667, 120.

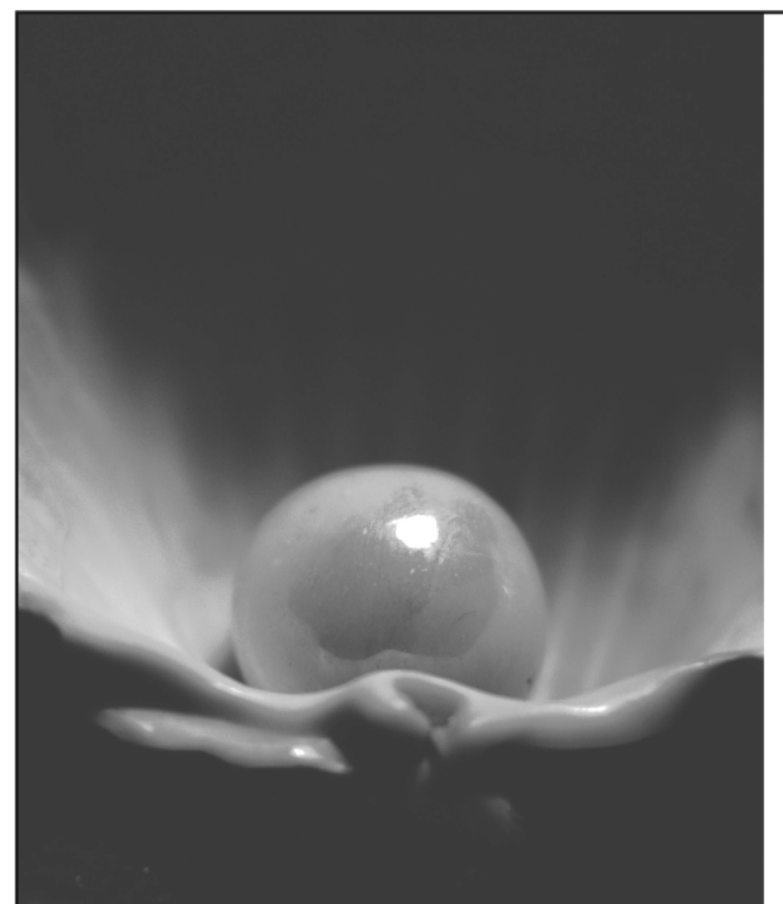

\section{Looking for that Special chemical science research paper?}

TRY this free news service:

\section{Chemical Science}

- highlights of newsworthy and significant advances in chemical science from across RSC journals

- free online access

- updated daily

- free access to the original research paper from every online article

- also available as a free print supplement in selected RSC journals.*

${ }^{*}$ A separately issued print subscription is also available.

Registered Charity Number: 207890 